\title{
Characterization of Human Cutaneous Lipophilic Diphtheroids
}

\author{
By R. F. SMITH \\ Department of Microbiology, Temple University School of Pharmacy, \\ Philadelphia, Pa., U.S.A.
}

(Accepted for publication 14 November 1968)

\begin{abstract}
SUMMARY
Sixty lipophilic diphtheroids (LD) isolated from human skin were characterized by a variety of morphological, biochemical, physiological and nutritional tests. The LD strains were tentatively placed into six fermentative groups and one non-fermentative group. Most LD strains required amino nitrogen, others required vitamins plus amino acids for growth. Nine LD isolates initiated growth with ammonia as a sole nitrogen source. Urea and nitrate were not utilized. A total of 149 cutaneous bacteria were compared for esterase and lipase action. Esterase activity was common but few LD strains appear capable of obtaining their required lipids by their own lipase action. The grouping scheme derived from studies with the $60 \mathrm{LD}$ strains was tested as a screening procedure to recognize and categorize other LD strains. A second series of II5 cultures from seven cutaneous sites were isolated. Six of the original seven groups were identified and one additional subgroup was formed. The screening method was partially effective as a means of studying the location and types of LD strains on skin. There were 3I strains which by determinative features could be grouped as Corynebacterium xerosis-like species. Human skin appears to have an unrecognized diversity of lipophilic corynebacteria yet to be classified into species.
\end{abstract}

\section{INTRODUCTION}

Normal human skin contains a relatively stable microflora although the numbers of bacteria present on skin may vary considerably depending on the site sampled (Marples, I965). The predominant bacteria are the Gram-positive, coagulase-negative staphylococci or micrococci, aerobic diphtheroids and Corynebacterium acnes which is anaerobic and resides primarily in pilosebaceous units. There are also yeasts usually classified as Pityrosporum species (Pillsbury \& Rebell, 1952). A small percentage of people may be carriers of coliforms or bacteria of the tribe Mimeae (Taplin, Rebell \& Zaias, 1963).

Few studies have been conducted on the ecological associations among the autochthonous skin bacteria. Some resident skin bacteria may provide certain factors which act as defence against invasion by other non-cutaneous organisms (Marples, 1965).

A large group of bacteria commonly isolated from normal skin are designated lipophilic diphtheroids (LD) because they require certain lipids for growth in vitro (Pollock, Wainwright \& Mansion, 1949). This LD group has been relatively obscure taxonomically although some authors consider LD skin species identical to Corynebacterium xerosis (Pillsbury \& Kligman, 1954). Evans (1968) recently attempted to classify cutaneous aerobic diphtheroids. The LD groups was not specifically sought 
but Evans was able to identify some of her isolates as $C$. xerosis or other recognized corynebacteria species.

This study was conducted to characterize LD strains from normal human skin and to compare them with several known species of the genus Corynebacterium and other closely related bacteria, to determine if LD strains can be classified as $C$. xerosis or its variants, and to compare their lipolytic activity and nutritional requirements to other groups of cutaneous bacteria. An attempt was made to measure the cutaneous distribution of LD strains by using a selected number of minimal screening tests.

The characterization of LD strains was considered a necessary preliminary to more satisfactory ecological investigations of the cutaneous diphtheroids and other skin bacteria.

\section{METHODS}

Reference strains. Cultures (Table I) were maintained on slopes of Todd-Hewitt agar (BBL; Baltimore Biological Laboratories, Baltimore, Md., U.S.A.) except for Propionibacterium acnes, which was kept in thioglycollate, and strains of Corynebacterium bovis, which were maintained on trypticase soy (TS) agar without glucose (BBL) containing $0.1 \%$ Tween 80 . Stock cultures were stored at $4^{\circ}$.

$\begin{array}{ll}\text { Table I. Designations and origin of reference strains } \\ \text { Strain } & \text { Source* } \\ \text { Brevibacterium linens } & \text { ATCC9172 } \\ \text { Microbacterium lacticum } & \text { ATCC } 8180 \\ \text { Listeria monocytogenes } & \text { ATCC } 15313 \\ \text { Mima polymorpha } & \text { ATCC I4291 } \\ \text { Kurthia zopfi } & \text { ATCC6900 } \\ \text { Propionibacterium acnes } & \text { ATCC I1828 } \\ \text { Corynebacterium diphtheriae } & - \\ \text { C. striatum } & \text { ATCC 6940 } \\ \text { C. xerosis } & \text { ATCC 373, 7064 } \\ \text { C. pseudodiphtheriticum } & \text { MWCS 29 } \\ \text { C. minutissimum } & \text { MWCS 28 } \\ \text { C. bovis } & \text { ATCC23346, 23347, 23348, 23349 } \\ & \text { ATCC7715, NIRD65, } \\ & 77,120,122,125,151,29\end{array}$

* ATcc, American Type Culture Collection, Rockville, Maryland, U.S.A. Mwcs, Midwest Culture Service, Terra Haute, Indiana, U.S.A. NIRD, National Institute for Research in Dairying, Reading, United Kingdom. C. diphtheriae was obtained from H. M. Cobe, C. minutissimum strains from D. Taplin, and the NIRD strains from D. J. Jayne-Williams. All other strains were obtained directly from the culture service indicated.

Isolation of cutaneous strains. Various sites on the skin of 62 students and six staff members were rubbed with cotton-wool swabs in Triton phosphate buffer (Williamson \& Kligman, 1965). Swabs were directly streaked on media or first mixed in $5 \mathrm{ml}$. of buffer to express the bacteria from the swabs. Loopfuls of diluent were then streaked on plates. Gram-positive cocci were isolated on mannitol salt agar (BBL) and classified by the methods of Baird-Parker (1963). mimeae-like bacteria were isolated on MacConkey agar (BBL) and identified by the methods of Taplin et al. (I963). The LD strains were isolated on $5 \%(\mathrm{v} / \mathrm{v})$ human blood agar by the method of Smith \& Willett (I968). They were maintained on the same slopes as were the Corynebacterium bovis strains. 
Lipid growth requirements. The LD strains were separated from non-lipid-requiring strains by inoculating TS broth as a base medium and TS broth containing $0.1 \%$ Tween 80. Isolates which grew in the latter medium only were considered LD strains. To confirm the lipid requirement, nutrient broth (Difco) was extracted twice with equal volumes of chloroform to remove lipids and dispensed in glassware washed with chloroform and methanol. Strains which grew in this broth only after the addition of $0.5 \%$ Tween 80 or I0 $\mu \mathrm{g}$. sodium oleate $/ \mathrm{ml}$. were considered obligate LD strains.

Characterization tests. Tween $80(0.05 \%)$ was added to all media used in this group of tests.

Growth studies. Forty-eight hr TS broth cultures were streaked on TS agar and incubated at 37 and $22^{\circ}$, in candle jars $\left(10 \% \mathrm{CO}_{2}\right)$ and in Brewer jars for anaerobic growth. Phenethyl alcohol agar (PEA) (BBL) was incubated aerobically at $37^{\circ}$. Filter sterilized sodium azide and potassium tellurite were added to TS broth. One loopful of each $48 \mathrm{hr}$ culture was inoculated into each of two TS broths. One acted as a control and the other was heated in a $60^{\circ}$ water bath for $30 \mathrm{~min}$. The tubes were removed, rapidly cooled and incubated at $37^{\circ}$. Nutrient broth was adjusted to $\mathrm{pH} 5 \cdot 0,6 \cdot 0,7^{\circ} \mathrm{O}$ and 8.0 electrometrically to determine ability to initiate growth in these broths.

Biochemical tests. Action on egg yolk was tested by the method of Esselmann \& Liu (I96I). Methyl red and Voges-Proskauer tests were determined with MR-VP broth (BBL). Nitrate reduction was determined with nitrate broth (BBL) and Bacto-Peptone broth (Difco) was used for indole production. Extracellular nuclease activity was measured by the methods of Smith \& Bodily (1968). Phosphatase activity was measured by the method of Baird-Parker (1963). Kligler iron agar and s.I.M. (sulphide-indolemotility) agar (BBL) were used to detect hydrogen sulphide production. Haemolysis was observed on $5.0 \%(\mathrm{v} / \mathrm{v})$ whole unwashed human blood agar. The remaining tests were conducted by the methods of Jayne-Williams \& Skerman (1966). Reagents were prepared according to standard methods (Manual of Microbiological Methods, 1957). Cultures were observed and tested in media from I to 8 days except litmus milk, which was incubated for 15 days.

Carbohydrate fermentations. Carbohydrates were incorporated into phenol red broth base (BBL) in final concentrations of $0.5 \%$. Media were autoclaved at $10 \mathrm{lb} / \mathrm{in}^{2}{ }^{2}$ $\left(115^{\circ}\right)$ for $10 \mathrm{~min}$. and rapidly cooled to $25^{\circ}$ in a water bath.

Esterase and lipase activity. Substrates used in this section were obtained from the Nutritional Biochemical Corp., Cleveland, Ohio. Esterase action was determined using polyoxyethylene sorbitan derivatives of several fatty acids. Compounds were incorporated in TS agar without glucose containing $0.01 \% \mathrm{CaCl}_{2}$. Preliminary tests revealed that some Tween compounds were inhibitory to the LD strains at $1.0 \%$ concentrations. Growth was judged as retarded when poor growth or no growth occurred on agar with substrate concentrations from $0 \cdot 1$ to $\mathrm{I} \cdot 0 \%$. Inhibition was considered to have occurred when growth developed at lower but not higher substrate concentrations. Each Tween was tested to find the concentration permitting growth of all LD strains. Esterase action was noted by the formation of cloudy zones around and beneath the colonies resulting from calcium soap formation. Triacetin hydrolysis was measured by the method of Davis \& Ewing (1964). Lipase action of emulsified substrates was observed on Spirit blue agar (Difco) using the methods of Smith \& Willett (1968).

Nutritional studies. A medium used as a minimal salts medium had the following 
composition per litre: anhydrous $\mathrm{K}_{2} \mathrm{HPO}_{4}, 700 \mathrm{mg}$.; $\mathrm{KH}_{2} \mathrm{PO}_{4}, 300 \mathrm{mg}$.; $\mathrm{MgCl}_{2}$, $100 \mathrm{mg}$.; $\mathrm{NaCl}$, I00 mg.; $\mathrm{MnCl}_{2}, 4 \mathrm{H}_{2} \mathrm{O}$, I0 mg.; $\mathrm{FeCl}_{3}$, I0 mg.; $\mathrm{CaCl}_{2}$, I mg. This medium was supplemented with combinations of $\mathrm{NH}_{4} \mathrm{Cl}$, I g. (w/v); glucose, Io $\mathrm{g}$. (w/v); vitamin-free Casamino acids (Difco), Io g. (w/v); urea (filter sterilized) or $\mathrm{KNO}_{3}$, I g. (w/v); and Tween $80,0.05-0.10 \%$. All batches of media were adjusted to $\mathrm{pH}$ 7.2. Vitamins sterilized by filtration were added alone or in combination in final concentrations of $10-100 \mu \mathrm{g} . / \mathrm{ml}$. These included riboflavine, niacin, nicotinic acid, thiamine and sodium pantothenate. Sodium oleate (I-Io $\mu \mathrm{g}$./ml.) was used as a substitute for Tween 8o. In some experiments carbon assimilation was compared with $0.06 \mathrm{M}$-glycerol, glucose and the sodium salts of acetate, citrate and lactate. Growth measurements were made in a Bausch and Lomb Spectronic-20 colorimeter.

Screening tests. A second series of LD strains was isolated from various cutaneous sites. Each strain was examined for its Tween 80 growth requirement, Tween 80 hydrolysis, growth on and hydrolysis of tributyrin and triolein, growth in $9.0 \% \mathrm{NaCl}$ broth, nitrate reduction and the fermentation of glucose, maltose, fructose, galactose, sucrose, lactose and salicin. The isolates were grouped on the basis of test results from the initial group of LD strains.

\section{RESULTS}

General characterization tests. Sixteen of the reference bacteria were compared with 60 LD strains (Table 2). Listeria monocytogenes was the only species which was motile, produced haemolysis and hydrolysed aesculin. An opaque lecithinase type reaction was produced on egg yolk agar. Brevibacterium linens produced a distinct orange pigment on solid media and produced a lecithinase reaction on egg-yolk agar surrounded by an outer clear proteolytic zone. The three Corynebacterium xerosis strains produced a pale yellow to tan pigment; $C$. xerosis ATCC 373 formed rough dry colonies and the other two strains were smooth.

Morphologically, the 6o LD strains were non-acid fast, asporogenous and pleomorphic. Generally, there was a lack of metachromatic granules in the organisms but always a tendency to form palisades (PI. I, fig. I-4). Strains varied from small coccobacilli to longer bacillary forms both straight and club-shaped. None of the LD strains produced pigments as did the Corynebacterium xerosis strains. Colonies were smooth, entire, raised and butyrous in consistency. There were no rough colony types formed. During the course of I yr. in which the isolates were maintained and repeatedly subcultured, only four $(6.6 \%)$ of the strains lost their obligate in vitro requirement for oleate or Tween 80 . The 60 strains were catalase positive and initiated growth in $10 \%$ $\mathrm{CO}_{2}$ in air and at $\mathrm{pH} 6 \cdot 0,7 \cdot 0$ or $8 \cdot 0$. The group was uniformly negative in the following characters: anaerobic growth, gas production from carbohydrate fermentation, motility, growth in $0.1 \%$ sodium azide and potassium tellurite, urease, gelatinase, haemolysis and action on egg yolk agar. There were no changes detected in litmus milk after I5 days incubation. Hydrogen sulphide and indole were not produced by any test organisms. None of the strains hydrolysed aesculin or fermented lactate, glycerol and mannitol. The LD strains were variable in the remaining tests. They were arranged into seven subgroups by their fermentation reactions. Groups I-VI were fermentative and group VII was non-fermentative. Group I differed from the other fermentative groups by fermenting lactose, trehalose and salicin, and produced an acid butt and slant on Kligler agar, as did Listeria monocytogenes. The remaining LD 


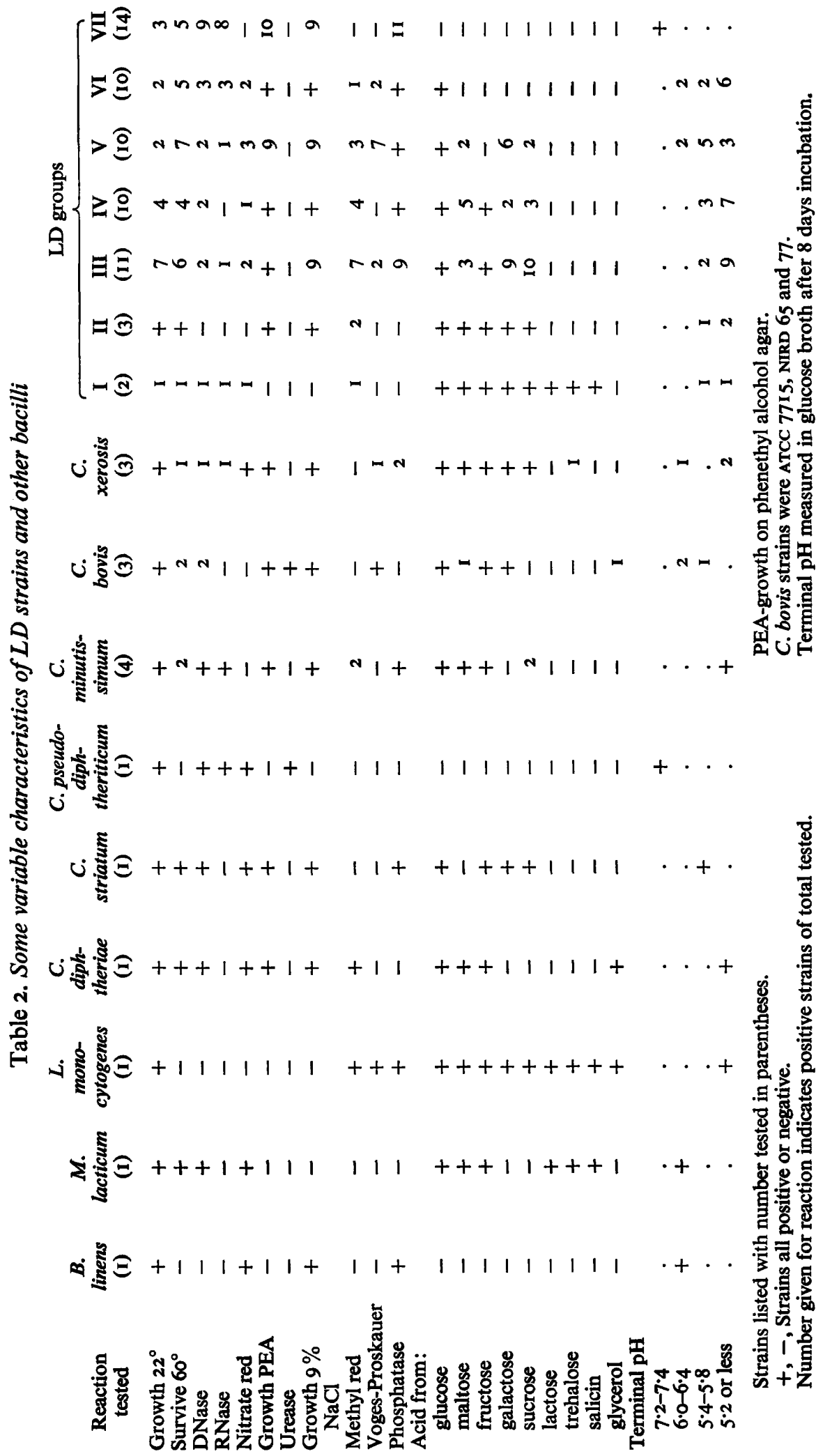


groups produced a weakly positive acid butt and alkaline slant or were negative. Group II fermented glucose, maltose, fructose, galactose and sucrose, as did the $C$. xerosis strains. Groups III-V were separated on the basis of the number and combinations of four sugars (maltose, galactose, fructose and sucrose) which were fermented. Group III fermented three of four sugars. Group IV fermented two sugars and group V only one sugar. Within each group no strain differed from any other by more than one reaction among the four sugar tests. Group VI fermented only glucose. Twenty-two strains grew at $22^{\circ}$ and 32 survived $60^{\circ}$. Nuclease activity was variable and produced mostly by group VII. Forty-eight strains grew in $9 \% \mathrm{NaCl}$ broth.

Table 3. Comparative esterase and lipase activity of various human skin bacteria and others

\begin{tabular}{|c|c|c|c|c|c|c|c|c|c|c|}
\hline \multirow[b]{3}{*}{ Organisms } & \multirow{3}{*}{$\begin{array}{l}\text { No. of } \\
\text { strains } \\
\text { tested }\end{array}$} & \multicolumn{9}{|c|}{ Hydrolysis of } \\
\hline & & \multicolumn{5}{|c|}{ Tweens } & \multirow{2}{*}{$\begin{array}{c}\text { Tri- } \\
\text { butyrin }\end{array}$} & \multirow[b]{2}{*}{$\begin{array}{l}\text { Tri- } \\
\text { olein }\end{array}$} & \multirow[b]{2}{*}{$\begin{array}{l}\text { Methyl } \\
\text { oleate }\end{array}$} & \multirow[b]{2}{*}{$\begin{array}{l}\text { Cotton- } \\
\text { seed oil }\end{array}$} \\
\hline & & 20 & 40 & 60 & 80 & 85 & & & & \\
\hline $\begin{array}{l}\text { Gram-positive } \\
\text { cocci }\end{array}$ & 46 & 42 & 32 & 30 & 23 & 20 & 32 & 42 & 33 & 32 \\
\hline M. polymorpha & I & + & + & + & + & - & + & - & - & - \\
\hline Mima-like strains & 20 & + & + & + & + & - & + & - & - & - \\
\hline P. acnes & I & - & + & + & - & - & + & - & - & - \\
\hline K. zopfii & I & - & - & - & - & - & - & - & - & - \\
\hline B. linens & I & + & + & + & + & + & + & + & + & + \\
\hline M. lacticum & I & - & - & - & - & - & - & - & - & - \\
\hline L. monocytogenes & I & + & + & + & - & - & - & - & - & - \\
\hline C. diphtheriae & I & - & - & - & - & - & + & - & - & - \\
\hline C. striatum & I & + & + & + & + & + & + & - & - & - \\
\hline $\begin{array}{l}\text { C. pseudodiph- } \\
\text { theriticum }\end{array}$ & $\mathbf{I}$ & + & + & + & + & - & + & - & - & - \\
\hline C. minutissimum & 3 & + & + & + & + & + & + & - & - & - \\
\hline C. xerosis & 3 & + & + & + & I & - & I & - & - & - \\
\hline C. bovis & 8 & 5 & I & $\mathbf{N}$ & - & 7 & $\mathbf{N}$ & - & - & - \\
\hline \multicolumn{11}{|l|}{ LD strains: } \\
\hline Group I & 2 & I & I & I & - & - & - & - & - & - \\
\hline II & 3 & 3 & 3 & 3 & 3 & - & - & - & - & - \\
\hline III & II & + & + & 10 & + & 7 & I & - & - & - \\
\hline IV & I0 & + & + & 9 & 9 & 8 & - & - & - & - \\
\hline V & IO & 9 & 9 & 4 & 8 & 5 & 3 & - & - & - \\
\hline VI & IO & + & $t$ & 8 & 8 & 3 & 2 & - & - & - \\
\hline VII & 14 & 10 & 10 & 6 & 7 & 3 & I & - & - & - \\
\hline $\begin{array}{l}\text { Total no. LD } \\
\text { strains active } \\
\text { on each } \\
\text { substrate }\end{array}$ & & 54 & 54 & 41 & 46 & 26 & 7 & 0 & 0 & ○ \\
\hline
\end{tabular}

Final test concentration for Tweens $20,40,60$ and 85 was $0.5 \%$; Tween 80 was $1 \cdot 0 \%$. Emulsified lipids were used in final concentrations of $0.5 \%$. ,,+- Strain or strains tested all positive or negative.

Numbers indicate strains positive if more than one tested.

$\mathrm{N}$, No growth on media.

Esterase and lipase activity. The bacteria were compared with cutaneous isolates of Gram-positive cocci and Gram-variable coccobacilli of the Mima-like group (Table 3). None of the 149 cultures tested hydrolysed $0.1 \%$ Tween 65 or degraded squalene. The test for triacetin hydrolysis was unreliable because incubation of the medium beyond 
3 days caused non-specific changes in the agar. The strains were compared for their action on soluble Tween substrates, emulsified substrates and one oil. The results indicated that only Gram-positive cocci and Brevibacterium linens produced extracellular lipase capable of acting on long chain lipids. Mima polymorpha and the other Mima-like strains hydrolysed certain Tweens and tributyrin. They also had lecithinase activity when tested on egg agar and in egg-yolk broth, producing a ring of fatty curd in the latter medium. Tributyrin was hydrolysed by most of the non-lipophilic diphtheroids but this property was not always related to the strains' ability to hydrolyse Tweens or split emulsified lipid substances. Tweens 20, 40,60 and 80 and tributyrin did not support the growth of some Corynebacterium bovis strains. With the exception of certain group VII strains, the LD bacteria grew well on all Tween media. Seven strains hydrolysed tributyrin, 22 strains grew poorly on this medium and did not hydrolyse the substrate. There were $3 \mathrm{I}$ other LD strains which grew normally on tributyrin agar but did not produce a lipase. The Gram-positive cocci, non-lipophilic bacilli and the Mima group grew on squalene media but the LD strains and C. bovis cultures did not grow.

Table 4. Nutritional patterns of LD strains and other bacilli

\begin{tabular}{|c|c|c|c|c|}
\hline \multirow[b]{2}{*}{ Organisms } & \multirow[b]{2}{*}{$\begin{array}{c}\text { No. of } \\
\text { strains tested }\end{array}$} & \multicolumn{3}{|c|}{ Nitrogen source } \\
\hline & & Ammonia & $\begin{array}{l}\text { Amino acids } \\
\text { required }\end{array}$ & $\begin{array}{l}\text { Amino acids and } \\
\text { vitamins required }\end{array}$ \\
\hline B. linens & I & + & - & - \\
\hline M. lacticum & I & - & - & + \\
\hline L. monocytogenes & I & - & + & - \\
\hline C. diphtheriae & 1 & - & + & - \\
\hline C. striatum & I & - & + & - \\
\hline C. minutissimum & 2 & - & + & - \\
\hline C. pseudodiphtheriticum & I & - & + & - \\
\hline C. xerosis & 2 & - & + & - \\
\hline C. bovis & 6 & + & - & - \\
\hline LD strains: & & & & \\
\hline Group I & 2 & - & $\mathbf{I}$ & I \\
\hline II & 3 & - & 2 & I \\
\hline III & II & - & 6 & 5 \\
\hline IV & 9 & I & 4 & 4 \\
\hline v & 7 & 6 & - & I \\
\hline VI & 8 & $\mathbf{I}$ & 5 & 2 \\
\hline VII & 12 & I & IO & I \\
\hline
\end{tabular}

Basal medium contained $\mathrm{NH}_{4} \mathrm{Cl}$, glucose and salts. Cultures were inoculated in TS Tween 80 broth as a growth control.

Number indicates strains positive of total tested.

Nutritional studies. Brevibacterium linens and Corynebacterium bovis utilized ammonia as a sole nitrogen source (Table 4). The other corynebacteria, including $C$. xerosis, required amino acids. Microbacterium lacticum did not grow without added vitamins. Urea as sole nitrogen source was utilized only by the $C$. bovis strains. None of the bacilli tested including the LD strains utilized nitrate as sole nitrogen source. The majority of the LD strains required nitrogen as $\mathrm{NH}_{2}$ in the form of casamino acids, others had an additional requirement for vitamins. The use of vitamins with $\mathrm{NH}_{4} \mathrm{Cl}$ did not replace casamino acids for those strains which required nitrogen as $\mathrm{NH}_{2}$. 
Group $\mathrm{V}$ had the largest number of ammonia-utilizing strains. The substitution of glucose in the basic medium by citrate, glycerol, lactate or acetate was not stimulatory to the majority of the strains. Only three LD strains were stimulated partially by acetate and glycerol.

Screening tests for distribution of $L D$ strains on skin. A second series of 115 strains was isolated from seven cutaneous sites to test the usefulness of the initial grouping scheme as a preliminary means of classifying these bacteria (Table 5). None of the isolates in this series fermented lactose or salicin, thus eliminating group I. All the strains grew in $9 \% \mathrm{NaCl}$ broth. There were 34 isolates mostly from the face, nose and toes which did not hydrolyse Tween 80 . Thirty strains grew on tributyrin agar but only 12 hydrolysed the substrate.

Table 5. Distribution and characteristics of LD strains from human skin

\begin{tabular}{|c|c|c|c|c|c|c|c|c|c|c|c|c|}
\hline \multirow{2}{*}{$\begin{array}{c}\text { Site } \\
\text { sampled }\end{array}$} & \multirow{2}{*}{$\begin{array}{l}\text { No. of } \\
\text { strains } \\
\text { isolated }\end{array}$} & \multirow{2}{*}{$\begin{array}{l}\text { Tween } \\
80 \text { not } \\
\text { hydro- } \\
\text { lysed }\end{array}$} & \multicolumn{2}{|c|}{ Tributyrin* } & \multicolumn{8}{|c|}{ Group } \\
\hline & & & Growth & lysis & I & II & III & IV & IV $a$ & $\mathbf{V}$ & VI & VII \\
\hline $\begin{array}{l}\text { Scalp } \\
\text { Face }\end{array}$ & $\begin{array}{r}26 \\
8\end{array}$ & $\begin{array}{l}5 \\
5\end{array}$ & $\begin{array}{l}5 \\
3\end{array}$ & $\begin{array}{l}\mathbf{I} \\
0\end{array}$ & $\begin{array}{l}0 \\
0\end{array}$ & $\begin{array}{l}0 \\
0\end{array}$ & $\begin{array}{l}4 \\
0\end{array}$ & $\begin{array}{r}12 \\
4\end{array}$ & $\begin{array}{l}7 \\
0\end{array}$ & $\begin{array}{l}I \\
4\end{array}$ & $\begin{array}{l}2 \\
0\end{array}$ & $\begin{array}{l}0 \\
0\end{array}$ \\
\hline Nose & 14 & 12 & 0 & 0 & 0 & 0 & 0 & 2 & 12 & 0 & 0 & 0 \\
\hline Axilla & 10 & 0 & 8 & 0 & 0 & I & 5 & 3 & 0 & 0 & I & 0 \\
\hline Sternum & $2 \mathrm{I}$ & I & I & 0 & 0 & 0 & 3 & IO & 3 & 2 & 2 & $\mathbf{I}$ \\
\hline Groin & 24 & 2 & I & 7 & 0 & I & 0 & 22 & I & 0 & 0 & 0 \\
\hline Toeweb & 12 & 9 & 0 & 4 & 0 & 3 & 0 & 9 & 0 & 0 & 0 & 0 \\
\hline Totals & II 5 & 34 & 18 & 12 & 0 & 5 & 12 & 62 & 23 & 7 & 5 & $\mathbf{I}$ \\
\hline
\end{tabular}

One or more isolates from the remaining six groups were recognized. The most commonly occurring type was groups IV (53\% of total). The groin area yielded the largest number of this group consisting of strains fermenting glucose, sucrose and fructose but not maltose or galactose. One additional group was recognized (IV $a$ ) as being identical to group IV but reducing nitrate. Nearly all of the strains in group IV $a$ were from the nasal area. Strains from the other groups did not reduce nitrate.

The strains in this series were examined for growth in media containing Tween 40, tripropionin, triolein, methyl oleate, methyl ricinolate and methyl palmitate. Tween 40 was split by all strains. Growth on tripropionin and methyl palmitate was poor or absent. Nine strains with apparent lipase activity from the face, scalp and nose were found. All acted on methyl ricinolate, three hydrolysed triolein and four split methyl oleate.

In the process of isolating LD strains 13 strains of contaminating Gram-positive cocci were found. This occurred because of their apparent requirement for Tween 80 . This was shown by inoculating mannitol salt agar with and without Tween 80 . Growth developed eugonically on the latter medium only and they were distinguished from the diphtheroids by Gram staining the cultures several times under different growth conditions. 


\section{DISCUSSION}

Determinative features of the reference group of bacteria were in general agreement with the recognized properties of these species (Bergey's Manual, 1957). These investigations also confirm the descriptions for Corynebacterium minutissimum and C. bovis as reported by Sarkany, Taplin \& Blank (1962) and Jayne-Williams \& Skerman (1966).

Diagnostically the LD strains fell into the family Corynebacteriaceae as they were Gram-positive, non-acid fast, non-motile, non-sporeforming, catalase-positive, aerobic, pleomorphic bacilli (Skerman, 1967). Human cutaneous diphtheroids have always been regarded as corynebacteria (Rosebury, 1962; Marples, 1965) and the data obtained in this study provide no evidence against this assumption. A precise distinction between the Brevibacterium and the Corynebacteriaceae does not exist but brevibacteria are not considered indigenous to man (Rosebury, 1962) and this group is usually not pleomorphic (Skerman, 1967). Harrington (1966) showed the similarity of nocardias, corynebacteria and mycobacteria. The familial status of human indigenous diphtheroids may be more difficult to resolve than recognition at the species or generic level. Pleomorphism offered little as an aid to species recognition or grouping of the LD strains.

The assumption that LD strains are identical with Corynebacterium xerosis is erroneous. Corynebacterium xerosis ferments glucose, maltose, fructose, galactose and sucrose and does not reduce nitrate or split urea (Bergey's Manual, 1957). These characters are used to separate $C$. xerosis from other closely related human species such as $C$. striatum, which has the same characteristics but usually ferments other sugars (Winford \& Haberman, 1966). Corynebacterium xerosis has no other known distinguishing diagnostic features. The three reference cultures of $C$. xerosis reduced nitrate. Evans (1968) identified as C. xerosis 23 non-lipophilic cutaneous diphtheroids which reduced nitrate, fermented glucose, sucrose and weakly fermented maltose. She identified as $C$. striatum nitrate negative strains which fermented the three sugars. The $C$. striatum strain tested here reduced nitrate but did not ferment maltose. Assuming that $C$. xerosis reduces nitrate and ferments glucose, fructose, maltose, galactose and sucrose then none of the 60 initial LD strains were identical to C. xerosis. If C.xerosis is considered variable in nitrate reduction and in the fermentation of one of the above sugars except glucose then 3I LD strains (groups II and III) from both series of I75 strains could be tentatively identified as $C$. xerosis. The 3I strains mentioned would be overlooked, however, or considered biochemically inert if cultivated in media without Tweens or other lipids. Obligate lipid requirements are the important difference between LD strains and $C$. xerosis. Apart from those strains which resemble $C$. xerosis, a far greater number exist as unrecognized, unnamed corynebacteria on human skin. Few studies have been attempted to describe them (McBride, Freeman \& Knox, I968). None of the LD strains resembled $C$. tenuis, which has no lipid requirements (Crissey, Rebell \& Laskas, 1952), nor are they closely related to $C$. bovis or $C$. pyogenes, which do require lipids (Roberts, 1968).

The fermentation scheme used to group the LD strains was not intended as a classification but was a workable means to categorize the bacteria. Evans (1968) placed non-lipophilic cutaneous diphtheroids into seven groups by using nitrate and urease tests and the fermentation of glucose, sucrose and maltose. She found that most nitrate reducers, as in this study, were from the nasal area. Evans found another nitrate-positive 
group from the groin area that did not ferment sucrose. A similar group was not recognized in the present study.

The most commonly occurring LD strains fermented glucose, fructose and sucrose (group IV) and a second group (IVa) was identical to group IV except for nitrate reduction. These two groups may represent closely related common cutaneous bacteria. Within the groups differentiated, however, there were some strains which differed in their utilization of ammonia or need for amino acids or vitamins. Nutritional differences plus lipid requirements should have some priority in a natural classification for the LD strains.

Variations in growth and activity on lipid substrates by LD strains indicate the heterogenous nature of the lipid requirements and lipolytic activity of the groups. Apparently few strains can derive their required lipids by their own lipase action. Esterase action was a common feature of the groups. It appears that some ecological association exists between LD species which require lipids and the lipolytic Grampositive cocci of skin. On the other hand, cutaneous cocci are ureolytic (Auletta \& Kennedy, 1966) and the LD strains are not. Cocci may produce ammonia from urea which could be utilized by some skin diphtheroids.

Growth stimulation by various Tweens was not always related to hydrolysis of the compounds. Eugonic and sometimes retarded growth occurred on Tween media. If each Tween contained some free fatty acids or slowly released them for utilization by the bacteria then several fatty acids could support or inhibit growth. These include laurate (Tween 20), palmitate (Tween 40), stearate (Tween 60), and oleate (Tweens 80 and 85 ). The strains tested for Tween 40 hydrolysis were all positive. Palmitate is the most common fatty acid found in human surface lipids (Wheatley, 1963) but other fatty acids produced by skin or liberated from triglycerides by cocci may be available for the diphtheroids. A detailed study of the lipid requirements for each designated group of LD strains is in progress and is required before further consideration can be given to each group as a species.

The method of Evans (1968) and the screening and grouping scheme reported here can be useful for presumptive studies of the aerobic cutaneous diphtheroids.

\section{REFERENCES}

Auletta, A. E. \& Kennedy, E. R. (1966). Deoxyribonucleic acid base composition of some members of the Micrococcaceae. J. Bact. 92, 28.

BAIRD-PARKER, A. C. (1963). A classification of micrococci and staphylococci based on physiological and biochemical tests. J. gen. Microbiol. 30, 409.

Bergey's Manual of Determinative Bacteriology. (1957). 7th ed. Ed. by R. S. Breed, E. G. D. Murray and N. R. Smith. Baltimore: Williams and Wilkins.

Crissey, J. T., REBeLL, G. M. \& LASKAS, J. (1952). Studies on the causative organism of Trichomycosis axillaris. J. invest. Dermatol. $19,187$.

Davis, B. R. \& EwING, W. H. (1964). Lipolytic, pectinolytic and alginolytic activities of Enterobacteriaceae. J. Bact. 88, 16.

EsselmanN, M. T. \& LIU, P. V. (I96I). Lecithinase production by Gram-negative bacteria. J. Bact. 81, 939.

Evans, N. M. (1968). The classification of aerobic diphtheroids from human skin. Br. J. Dermatol. 8o, 81 .

HarRington, B. J. (1966). A numerical taxonomical study of some corynebacteria and related organisms. J. gen. Microbiol. 45, $3 \mathrm{I}$.

JAYNe-Williams, D. J. \& Skerman, T. M. (1966). Comparative studies on coryneform bacteria from milk and dairy sources. J. appl. Bacteriol. $29,72$. 
Manual of Microbiological Methods. (1957). Society of American Bacteriologists. New York: McGraw-Hill.

MARPLeS, M. S. (1965). The Ecology of Human Skin. Springfield, Ill.: C. C. Thomas.

McBride, M. E., Freeman, R. G. \& Knox, J. M. (I968). Characterization of keratinophilic corynebacteria. Bact. Proc. p. 78.

Pillsbury, D. M. \& Kligman, A. M. (1954). Some current problems in cutaneous bacteriology. In Modern Trends in Dermatology. Ed. by R. M. B. MacKenna. New York: P. Hoeber, Inc.

Pillsbury, D. M. \& Rebell, G. (1952). The bacterial flora of the skin. J. invest. Dermatol. 18, 173.

Pollock, M. R., WaINWRIGHT, S. D. \& Mansion, E. D. (1949). The presence of oleic acid requiring diphtheroids on human skin. J. Path. Bact. 6r, 274.

RoBerTs, R. J. (1968). Biochemical reactions of Corynebacterium pyogenes. J. Path. Bact. 95, 127.

Rosebury, T. (1962). Microorganisms Indigenous to Man. New York: McGraw-Hill.

Sarkany, D., Taplin, D. \& Blank, H. (1962). Erythrasma, a bacterial disease. Excerpta Medica Int. Congress. Series 55, roro.

SKERMAN, V. B. D. (1967). A Guide to the Identification of the Genera of Bacteria. Baltimore: Williams and Wilkins.

SMIth, R. F. \& BodLy, H. L. (1968). Characterization of anaerobic diphtheroids. Hlth. Lab. Sci. 5, 95.

Smith, R. F. \& Willett, N. P. (1968). Lipolytic activity of human cutaneous bacteria. J. gen. Microbiol. 52, 44I.

TAPLIN, D., REBELL, G. \& ZAIAS, N. (I963). The human skin as a source of Mima-Herellea infections. J. Am. med. Ass. 186, 952.

Wheatley, V. R. (1963). Problems in the analysis of sebum. In Advances in the Biology of Skin, 4, 135. New York: MacMillan Co.

Williamson, P. \& KLIGMan, M. (1965). A new method for the quantitative investigation of cutaneous bacteria. J. invest. Dermatol. $45,498$.

WINFORD, T. E. \& HABERMAN, S. (I966). Isolation of aerobic Gram-positive filamentous rods from diseased gingivae. J. dent. Res. 45, I1 59.

\section{EXPLANATION OF PLATE}

Morphology of representative LD strains and Corynebacterium xerosis. Gram stain of $48 \mathrm{hr}$ cultures grown on TS Tween 80 agar. Magnification, $\times 970$. Bar in photographs represents $5 \mu$.

Fig. I. Corynebacterium xerosis ATcc 373.

Fig. 2. LD strain 54, small coccobacilli.

Fig. 3. LD strain 5I, intermediate size oval-shaped cells with one swollen end.

Fig. 4. LD strain 40, largest type with more even bacillary shape. 

Journal of General Microbiology, Vol. 55, No. 3

Plate I
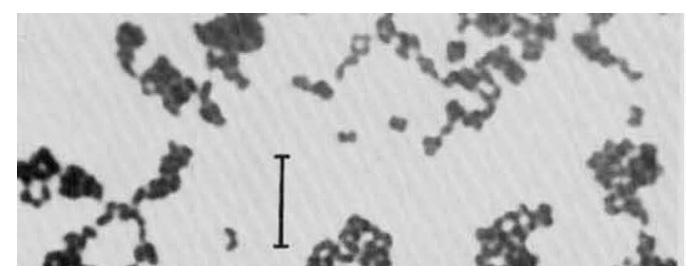

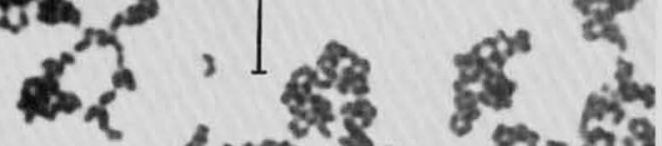
4hase - purs?

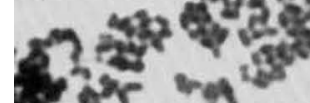

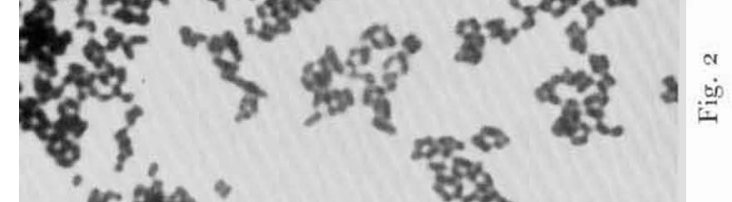

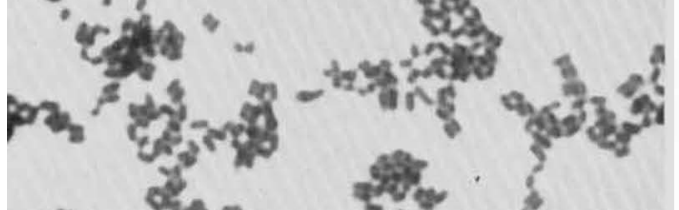
- ते $^{2}$ ?
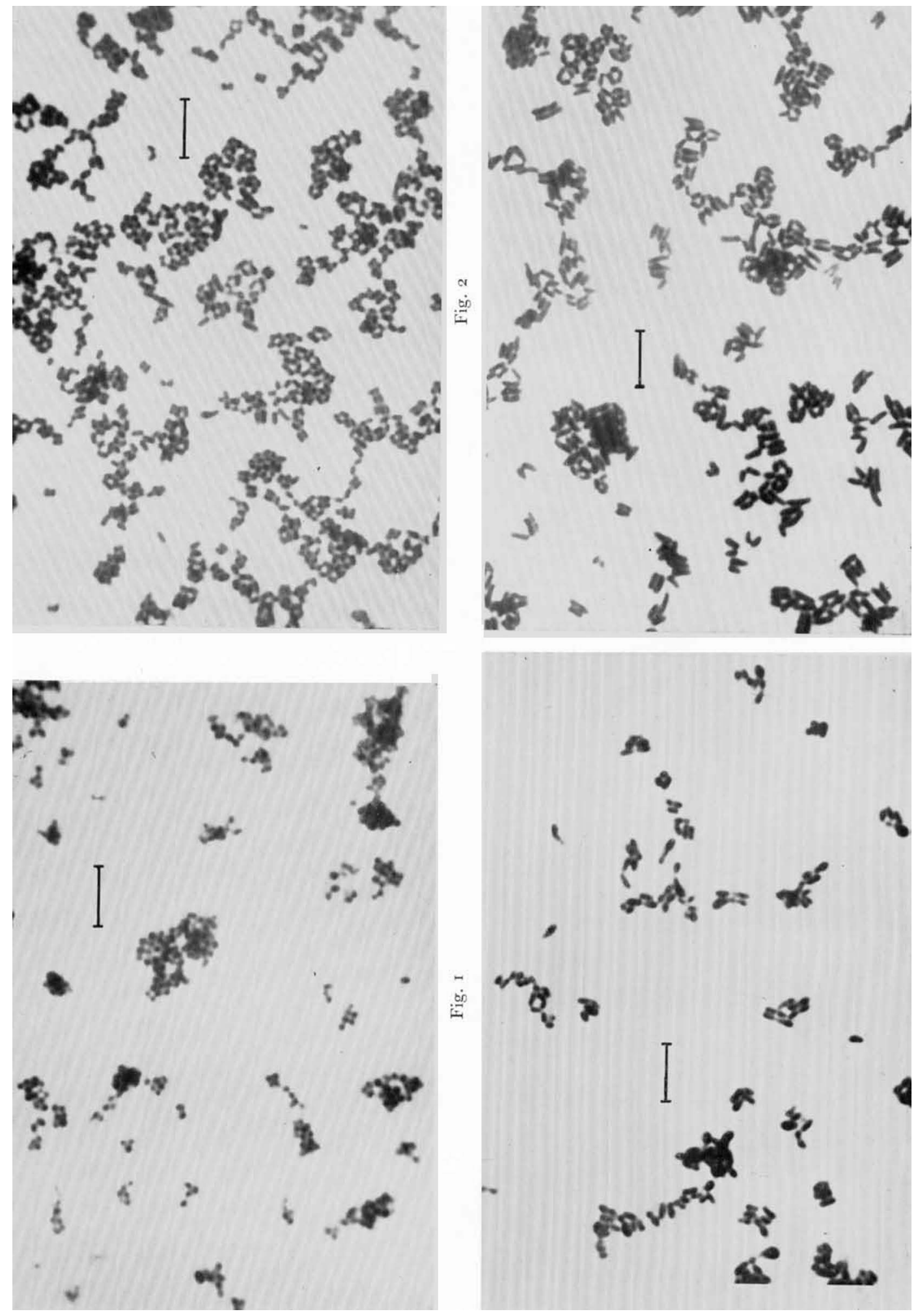